する一般的要求事項を補足するものである.

この主な内容としては

・線質

・X線ビーム範囲の制限及び表示

·X線照射野と受像面との関係

・漏扎放射線

·焦点皮虐間距離

・X線ビームの減弱

. 一次防護遮へい体

・迷放射線に対寸る防護

などから構成され，各国既存の規制との互換性を保ち ながら規定された。現在のところ，他委員会への確認 作業を行い，他の認証基準関係の規格とまとめ，今後 数回の分科会と本委員会の審議を経て，2005年 3 月に はJIS原案として日本規格協会へ提出する予定であ る。

（根岸 徹）

3-1-3 JIS原案作成分科会班(医用電子加速装置一安 全)

JIS Z 4705「医用電子加速装置一安全」1993年版の改 正を目的に，本年度JIS原案作成分科会が立ち上がっ た。この分科会には，本学会標準化小委員会より 4 名 の委員が参加し，作業を行った。旧JIS Z 4705はJIS形 式が翻訳JISを許容する以前の規格であるため，他の 規格と形式上の整合性や用語の統一といった面で，改 正の必要性があった規格である。このような問題点を 念頭に扔いた改正作業が行われ，本年度11月にJIS原案 作成本委員会へ提出した.

（保科正夫）

3-1-4 JIS原案作成分科会班(乳房用X線装置及び乳 房撮影定位装置一安全)

平成13年に，IEC 60601-2-45:1998 と国際整合性を 持つJIS Z 4751-2-45(IEC 60601-2-45:1999)「乳房用X 線装置及び乳房撮影定位装置一安全」が日本規格協会 より発行された。これまで乳房用X線装置に関する安 全規格がなく，近年，普及のめざましい乳房用X線装 置の安全規格として重要であった。しかし，この規格 では機械的安全やX線防護に関する内容は規定されて いるが，X線高電圧装置の安全要求などについての規 定がなく，懸案事項となっていた。このため，IECで は高電圧装置等の要求項目を追加, 修正したIEC 60601-2-45/Ed.2:2001を発刊した。それに伴い，JIS でも乳房用X線装置の高電圧装置の安全要求を早急に 確立する必要があり今年度IEC 60601-2-45/Ed.2:2001 のIDT規格としてJIS 60601-2-45の改正作業を行って いる．Ed.2では特に電源の危険に対する保護，作動デ ータの正確度及び危険な出力に対する保護について追 加され，高電圧装置の規定では管電圧，管電流，管電
流時間積の精度, $\mathrm{X}$ 線出力の再現性, $\mathrm{X}$ 線出力, $\mathrm{AEC}$ の安定性などが規定された。特に管電圧の精度は土5 \%以内であり，一般の高電圧装置 $( \pm 10 \%$ 以内 $)$ とは異 なっている. 現在, 3 回の分科会を重ね, 翻訳分担作 業とともに, 旧版との比較, 確認作業, JIS Z 4701, JIS Z 4702, JIS T 0601-1-3との照合など原案作業を 進めている. 今後数回の分科会と本委員会の審議を経 て，2005年 3 月にはJIS原案として日本規格協会へ提 出する予定である.

(安部真治)

\section{3-1-5 JIS原案作成分科会班(診断用一体形X線発生} 装置)

今年度は, JIS Z 4711 (診断用一体形X線発生装置) の改正作業を行った。

IEC 60601-2-7:1998を基に改正されたJIS Z 4702: 1999 (医用X線高電圧装置通則) と要求事項について整 合性を図り，装置の実態にあわせることを改正の方針 として審議を行った。

（浅野 宏）

\section{3-2 写真感光材料工業会関連 \\ 今年度はWGとして審議はなかった。}

（設楽 明）

\section{4. 医用画佰部門における不变性試験の実践のための 検討委員会}

「医用画像部門の品質維持の評価及び日常試験」一 JISにおける不変性試験マニュアルーというタイトル (仮称)でJIS化された不変性試験の実施を行うための マニュアルの作成計画を行った。これまで，不変性試 験のJIS化を進めてきたが，これらの日常試験を普及 させるためにも，このマニュアルの作成が必要である ことから，来年度の発刊に向け準備を進めている.

(北村善明)

\section{IEC関運規格, JESRA規格班活動}

\section{5-1 IEC/SC62B対策専門委員会班}

2003年 9 月30日にFrankfultでIEC-TC62/SC62Bの会 議が開催され，SC62B日本から幹事の幾瀬純一が出席 した。下記にWGの報告概要を記す。

1)WG-23 \& MT-30「医用X線CT装置関係」

IEC 61223-3-5「医用X線CT装置の性能・受入試験 (案) 」62B/485/CDVが各国承認となり2004年 4 月に 発刊となった。

2)WG-28「MRI装置関係」

IEC 60601-33 Ed.2「磁気共鳴画像診断装置の安全 一第 2 版」の見直しを推進し，超伝導磁石における クエンチ発生時に備え，より安全な要望措置を包含 
した修正版にまとめることとした。

3)WG-33「ディジタル映像機器のDQE関係」

IEC 62220-Ed.1「ディジタル映像機器の特性一 DQEの決め方」の発刊が行われ, WG-33として, 乳 房用画像検出器と動態画像検出器分野IEC 62220seriesとし，進展を図ることとした。

4)WG-35「MRIの特性関係」

Committee-Draft $の$ 作業中.

5)WG-36「画像表示装置関係」

新規作業案件として承認され活動が行われる。

6) MT-30「医用X線CT装置関係」

IEC 60601-2-44Ed.2は国際科学出版物と整合した 定義に修正がされた。

7) MT-31「乳房用X線装置関係」

IEC 60501-2-45 Ed.2「乳房用X線装置の安全一第 2 版」㧍よびIEC 61223-3-2 Ed.1「乳房用X線装置の 受入試験」にディジタルX線検出器の取り込み作業 が始まった。

8)MT-32「X線源装置関係」

「診断用X線管焦点の特性」の見直しがされた。「診 断用回転陽極管の負荷特性」の見直しは2003年の年 度末に計画がされている。

9)MT-34「超音波画像診断装置関係」

見直し作業は再開され，MT-34として温度と電磁 場两立性の 2 点に絞り修正する。

IEC 60601-2-37Ed.1「超音波画像診断装置の安全 一第 1 版」の見直し版Ed.2はIEC 60601-1Ed.3「医用 電気機器一般安全通則」との整合性を図る作業が始 まる。

10)MT-38「透視・撮影装置関係」

IEC 61223-3-1「診断用X線装置の性能 - 受入試 験」, IEC 61223-3-3「DSA用X線装置の性能・受入試 験」, IEC 61223-2-9「診断用X線透視・撮影装置の不 変性試験」, IEC 61223-2-11「診断用直接撮影装置の 不変性試験」などを並行して見直しを行い，最新技 術の要求事項を取り入れる.

(宮㠃 茂)

\section{5-2 IEC/SC62C対策専門委員会班}

今年度はWGとして審議はなかった。

（保科正夫）

\section{5-3 X線発生装置・機械装置班}

\section{5-3-1 機械的安全}

今年度はWGとして審議はなかった。

\section{5-3-2Ｘ線管およびX線管装置}

(石川光雄)

IEC 60336 Ed.4 Medical electrical equipment X-Ray tube assemblies for medical diagnosis-characteristics of focal spots（診断用X線管装置の焦点特性）について， 翻訳し審議を行った. カメラ寸法および設置方法，焦 点寸法のあらわし方として変調伝達関数と線広がり関 数を同時に評価するなど焦点の寸法や形状など特性に ついて審議を行った。

次年度は, IEC 60601-2-28 Medical Electrical Equipment Part2: Particular requirements for the safety of $\mathrm{X}$ ray tube assemblies for medical diagnosis (医用X線源 装置及びX線管装置の個別安全規格)のJIS化を行うこ とになった。

（宮㟝 茂）

\section{5-3-3 X線高電圧装置}

今年度はWGとして審議はなかった。

(宮㟝 茂)

\section{5-3-4 X線装置防護}

今年度は62B/547/CD IEC 60601-1-3 Ed.2.0 Medical electrical -Part 1: General requirements for safety - 3 . Collateral standard: General requirements for radiation protection in diagnostic X-ray equipment (医用電気機 器 第一部：安全に関する一般的要求事項 第 3 節：副 通則 診断用X線装置における放射線防護に関する一 般的要求事項)について審議を行った。Ed.1と，これ までに出された個別規格で取り入れたX線防護の最新 要求との整合性を図るため，各国からのコメントと変 更点について審議を行った。この内容について次年度 も検討を継続する予定である。

（根岸 徹）

\section{5-3-5 乳房X線撮影装置}

今年度は，乳房用X線装置の安全規格であるJIS Z 4751-2-45:2001乳房用X線装置及び乳房撮影定位装置 一安全のJIS化改正作業を重点的に行った．JIS化作業 の他には，62B/526/CD IEC61223-3-2 Ed.2 Evaluation and routine testing in medical imaging departmentsAcceptance tests imaging performance of mammographic X-ray equipment (医用画像部門における品質維持の評 価及び日常試験方法一第3-2部：受入試験一乳房用X線 装置)について，Ed.1との変更点や新たに追加された CR，DRに関する審議を行った．試験機器では管電圧

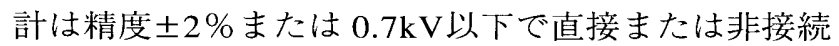
形にて測定とされている。PMMAの厚さは原案では 25，45，65mmであったが，25mmは日本人には厚す ぎるため $20 ， 45 ， 65 \mathrm{~mm}$ を提案した．HVLに使用する $\mathrm{Al}$ フイルタの純度は $99.9 \%$ 変更された。試験方法で 測定位置がHVLでは胸壁端から $6 \mathrm{~cm} ， \mathrm{X}$ 線出力では $5 \mathrm{~cm}$ であり，他の規格とも比較し，測定点の統一をす るよう提案した。またAECではF/Sシステム, CR · DRについて規定された，CRについてはメーカにより 
CNRの測定は困難との意見があり，S值で代用できな いか検討した．線量の上限，下限を取扱説明書に明示 すれば線量把握が可能ではとの意見があり，メーカで 検証することとし，これらの意見を集約し日本の意見 として提案することとした。

(安部真治)

\section{5-3-6 歯科用X線装置}

歯科用X線装置における適合性認定基準告示案作成 のための審議を行った。

また，JIS Z 4711の改訂準備を行い，JIS化委員会へ 引き継いだ。

\section{5-3-7 照射野制限装置}

（丸橋一夫）

今年度はWGとして審議はなかった。

（浅野 宏）

\section{5-4 X線用I.I.班}

今年度はWGとして審議はなかった。

(篠原文章)

\section{5-5 X線用TV班}

今年度はWGとして審議はなかった。

(篠原文章)

\section{5-6 ディジタルX線画像診断装置班}

IEC62220-1 (62220-1-2: Medical electrical equipment characteristics of digital X-ray imaging devices - Part 1: Determination of the detective quantum efficiency Section 2: Mammography detectors [62B/548/NP], 62220-1-3 Medical electrical equipment characteristics of digital X-ray imaging devices - Part 1: Determination of the detective quantum efficiency 3: Dynamic Imaging Detectors [62B/549/NP]) に対するIEC WG33会 議に西木, 山崎, 加野, 原, 小寺が出席した。IEC WG33会議で検討された内容の抜粋は以下のとおりで ある。一般X線撮影系のディジタルDQEでは，MTFに 関しては問題なく異なる算出アルゴリズムの比較が行 われた，DQEでは検討を継続する必要があり，テスト 用画像データでアルゴリズムの検証用途として利用 し，誤差を小さくするため62220-1規定に従うのが重 要とのことであった。マンモグラフィのディジタル DQEでは，撮影条件・撮影系に関しては日本のコメン トがほぼ通り，ヒール効果をどう扱うかは良いアイデ アが出ず，宿題項目となった．動画用ディジタルDQE ではI.I.-TV系は除き，線質・線量・フレームレートの 観点から規定を設けること，標準線質・lag correction はBastiaens(フィリップス)の宿題となった。これらの 経緯をふまえ前述の62B/548/NPおよび62B/549/NPが
2004年10月29日に発行され，投票期限は2005年 2 月 4 日となり審議を行っている.

(加藤 洋)

\section{5-7 X線CT班}

1) IEC 61223-2-6 Ed.2 CDV(不変性試験)の審議

X線CT装置の不変性試験に関するCDV文書が発 行され，CDV文書に対する投票が平成17年 3 月ま でに行われる。JIRAとしてはコメントを投票まで に検討する。

2) IEC 60601-2-44 (CT装置の個別規格) Ed.3 CD案の審 議

現在IEC60601-2-44の翻訳JIS原案 (JIS Z 4751-244 不変性試験：X線CT装置) は, 工業技術標準調査 会での審議待ちとなっているが, 現在, Ed.3CD文 書が発行された。この文書に宿題コメントを提出し たのは，JIRA (日本)とFDA (米国)であった。

3 ）適合性認証基準の審議

今年度も引き続き, CT装置の適合性認証基準に ついて，審議した，認証基準の基本要件のチェック リストの作成，付帯機能リストの検討を行った。ま た組み合わせCTのうちPET-CT, Angio-CTは個別 に装置基準とすることとして，機構と調整してい る.

4)IEC規格のJIS化に向けた準備

平成17年度に次のJIS原案作成が予定されてお り，JIS化のための翻訳作業を開始した。

(1) JIS Z 4751-2-44(CT装置の個別規格)の改正, IEC 60601-2-44 Amendment 1の適用

(2) IEC 61223-3-5 (CT装置の受入試験)の翻訳JIS (北村善明)

\section{5-8 核医学機器班}

1 ) IEC文書の審議を行った。

(1) IEC 61675-2 Am.1 Ed. 1.0: Radionuclide imaging devices - Characteristics and test conditions - Part 2: Single photon emission computed tomographs

(2) Nuclear medicine instrumentation-Routine tests

- Part 4: Radionuclide calibrators

2)PET装置に関するパブリックコメントに関する審議 厚生労働省よりPETの施設に関する医療法施行規 則の改訂のためのパブリックコメント意見書の要請 があった。工業会としてもガンマカメラによるPET 収集に関しては考慮してもらうようにコメントを提 出することとした。

3) ポジトロンCT機能付ガンマカメラに対する対処に ついて

(1) 法規委員より平成16年 7 月末厚生労働省発行のパ 
ブリックコメントに対する回答としてポジトロン CT機能付ガンマカメラに対し行政は認めていな いという発言があり，これに対する説明があっ た.また本件に関する対処としてはJIRAとして 行うので，個々のメーカおよび技師会から対処さ れるのは控えてほしい.

(2)SC4401委員会としては認証基準作成などの対応 をとる。

4) JIRA認証基準作成WGで，付帯機能リストを各SC で作成した。

(金谷信一)

\section{5-9 MR班}

1) IEC文書審議状況

(1) IEC60601-2-33 Ed.2.0磁気共鳴画像診断装置一安 全は2002年 5 月に発行された。その後本規格で はMRI装置のクエンチ発生時の安全予防措置に関 する付属文書IEC60601-2-33 Ed.2.0 Amd.1として 2005年発行を予定されている。本付属文書は 2004年 9 月 10 日に投票が締め切られ，25力国の 投票があり賛成 19 , 裹権 $6,76 \%$ の賛成で承認さ れた。

IEC60601-2-33 Ed.3.0:IEC60601-2-33 Ed.2.0 磁 気共鳴画像診断装置一安全は, 2005年 6 月まで 変更されないが，静磁場の健康への影響他の検討 項目を加え，新たに規格を見直すべく，準備が進 められている。

(2) IEC62312-Ed.1.0

IEC62312-Ed.1.0 磁気共鳴画像診断装置一特性 は2002年 4 月WG35として活動を開始, MRIの性 能評価法に関する規格を審議している。

2) JIS化の状況

(1) JIS Z4951：(IEC60601-2-33 Ed.2.0 翻訳版)

JIS Z4951第 2 版磁気共鳴画像診断装置一安全 が2004年 7 月25日に発行された。

(2) IEC 62312-Ed.1.0

SC4402委員会ではIEC62312-Ed.1.0 磁気共鳴 画像診断装置一特性について現在JIS化を行うべ く翻訳ならびに内容審議を行っている．進渉状況 は最終段階にあるが，IEC WG35で変更・修正が 進行中であるため, JIS化は 1 年延長し2007年度 に行うこととした。

3) MR装置認証基準(案)の検討

$\mathrm{SC} 4402$ 委員会では2005年 4 月の改正薬事法施行 に向けて，MR装置認証基準(案)の内容の確認と審 議を行っている.

(春原信雄)
5-10 ポジトロンCT班

1) IEC文書の審議を行った。

IEC TR 61948-3: Nuclear medicine instrumentation

-Routine tests - Part 3: Positron emission tomographs

2)PET第三者認証 “付帯機能”作成について

平成16年12月13日開催予定の第21回認証基準WG までに，認証基準を作成したSC委員会はすべて“付 帯機能リスト”の作成が必要となったので，11月中 に各委員からデータを集め，12月初旬に一度サブ WGを開催して意志の統一を図る.

3) JESRA-X73の審議

新しいJESRAへの改訂の方針は以下のように決ま った。

(1) 現在のJESRAはIECを取り込んでいるが，3D収 集の性能評価が必要なことを考えると，NEMA を取り込まざるを得ない。

一旦現行JESRAをIEC化して，NEMAを取り込 む.

(2) FDGデリバリでPET検査を考えている施設への配 慮

「実用領域での計数率」，「実用的な核種の選択」 など“適用範囲”にて指導する。

(3)次回のSC4405委員会に, IEC化したJESRAX0073を用意(佐藤)するので，それを吒き台とし て審議を進める。

（織田圭一）

\section{5-11 放射線治療機器班}

JIS Z 4705「医用電子加速装置－安全」1993年版の改 正と改正薬事法のガイドライン作成作業を行った。 ガ イドライン作成はシミュレータと加速器について項目 の検討を行い，審査基準についてJIRA基準委員会に 対して提出をした。

（保科正夫）

\section{5-12 線量計班}

医用電気機器一密封小線源治療用線量測定機器パー ト 1：ウエル型チェンバを用いた機器 (Medical Electrical Equipment. Dosimetric instruments as used in brachytherapy - Part 1: Instruments based on well-type ionization chambers）は投票の結果，否決された。

（津田政行）

\section{$5-13$ X線防護班}

本年度は，医用画像部門における品質維持の評価及 び試験方法一第2-8部：不変性試験一X線防護具類特に 放射線診断検査中に操作者と患者を保護するために使 用される防護用具の試験手順およびデー夕評価の再確 
認とユーザーに対する普及㤵蒙のあり方についてJIRA 側と検討した。

（伊藤敏夫）

\section{5-14 用語班}

今年度はWGとして審議はなかった。

(篠原文章)

\section{5-15 品質保証班}

品質保証班の主な活動は，最新のIEC規格動向の把 握，JIS化の検討及び制定されたJIS規格のガイド作 成，関連分野の歴史，開発経緯の分類・整理及び技術 資料の作成などである。最近のIEC規格 (IEC-TC62/ SC62B\&C：画像診断機器\&放射線治療機器の主要国 際規格)の動向及びJIS化の動向をさぐり，品質保証班 として審議可能な規格やガイド案の検討を行った。今 回，平成13年度にJIS改正作業が行われたJIS Z 4704: 200X (医用X線管装置通則)のJIS規格ガイドを作成 L, MRC情報Vol.13 No.2(平成16年 8 月)に揭載し た.今回のガイドは新JIS Z 4704の規格発行が遅れて おり，JIS発行前の掲載となった。また，前回JISガイ ド案の検討を行ったJIS Z 4752-3-1受入試験一診断用 X線装置が平成16年 7 月に日本規格協会より発行され たため，JIS Z 4752-3-1 ガイドも逐次MRC情報に掲載 される宁定である。

また，今年度の新しいJISガイド案として平成16年 3 月に審議終了のJIS Z 4752-2-11 不変性試験，直接撮 影用X線装置の検討を開始した。本JISに関連した本学 会標準化小委員会の委員 2 名の参加を得て, JIRA と 共同でガイド案の作成を行っている．今後も最新の IEC替格やJISを把握し, 逐次JISの普及に向けたガイ ド案の作成を継続していく予定である。

(安部真治)

\section{5-16 電波障害対策班}

近年，医療用具の電磁两立性 (EMC) に関する国際 標準化の必要性が叫ばれているなかで，わが国におい てもようやく国際レベルに準拠したEMC法制化(JIS) が発出され，平成19年 4 月 1 日までの間で順次法的 規制が開始された。一方，欧米のEMC先進国を中心 とした国際動问としては，EMC第 1 版規格の問題点 を改善した医用電気機器電磁両立性国際規格IEC 60601-1-2第 2 版EMC規格 (以下EMC第 2 版規格) が 2001 年発行された. 本年度は, EMC第 2 版規格の分 析とその対応について重点的に審議を行った。

1) EMC第 2 版規格への対応

EMC法規制の先進国であるEUにおいては1998年 からEMC第 1 版規格の適用が開始され，その後第
1 版規格の見直しが進められて，2004年11月にEMC 第 2 版規格への切り替えが決まっている. また，米 国内においても，Recognized Consensus Standerds として同じ国際規格が引用されており，EMC第 1 版 規格から第 2 版規格への切り替えが上述のEUと同 じ2004年11月に決まった。

EMC第 1 版規格ではEMI試験が 2 項目，Immunity試験が 4 項目であり, 合計 6 項目の試験が要求 されていた。しかしEMC第 2 版規格では試験項目 が追加され，EMI試験で 4 項目，Immunity試験で 7 項目, 合計11項目の試験が必要となった。またImmunity試験の合否判定には，医療機器のリスクマネ ジメント国際規格ISO14971を用いたりスク解析を 実施し, リスク解析を基に装置の必須性能や機能を 明確化したうえで，試験結果の合否を確認すること が決められた。

具体的には，装置の性能や機能の各項目をこのリ スク解析規格の手順に従って分析し, その結果装置 の必須性能や必須安全機能と考えられる項目がImmunity試験でその目的を達成できない状態になる場 合は試験不合格となることである。リスク解析を利 用して合否判定する方法は, 他の電子電機機器の $\mathrm{EMC}$ 規格にない医療機器EMC第 2 版規格の特徵で ある。来年度も継続してEMC第 2 版規格への対応 について審議していく予定である。

2) EMC第 2 版規格について使用者(学会員) 向け解説 の検討

新しい国際規格であるEMC第 2 版規格を，次の ような視点からとらえた解説文書を作成するべく検 討を行った。

(1) EMC第 2 版規格の背景 (なぜ早期に第 1 版から第 2 版への改善が進められたか)

(2) EMC第 1 版規格と第 2 版規格の試験項目数と特 徵について

(3) 各論-EMC第 1 版規格と第 2 版規格の変更点につ いて

(4) EMC第 2 版規格において新しく追加された試験 項目の概要について

(5) EMC第 2 版規格の効果について

現在，本誌に投稿準備中である。

3)医療施設におけるEMC環境の実態調査

新しい検討課題として医療施設におけるEMC環 境の実態調査を試みた。第 1 回目として埼玉県立小 児医療センターにて現地調査を実施した。調査した 箇所としては一般撮影室, 血管撮影室, CT検査 室, MRI検査室とし, 次に掲げた内容について調査 した。

(1) 各検査室に設置されている医用機器とIT機器との 
位置関係 (近接して配置および使用されているか) について

(2) 各医用機器およびIT機器のEMC規格取得状況 (機 器銘版等により確認する)について

(3)過去に発生したEMCに起因すると思われるトラ ブル事例について各担当者より聞き取り調査し た。

今後, 調査事例を増やし検討していく予定である。

4)EMC関連の外部委員会活動との連携

JIRAの上部団体である日医機協EMC委員会掞よ び関連団体である日本電子機械工業会と歩調を合わ せ医用電子機器の放射電磁測定に参加した。並行し て不要電波問題協議会イミュニティ委員会, 日本工 業標準調査会, 電気. 電子総合企画専門委員会, 厚 生労働省EMC研究班, 経済産業省電波障害問題調 查検討会, 消防庁「消防機関で使用する医療用電子 機器への電波の影響に関する委員会」電波産業会 等, 国内の関連委員会・団体と連携し, 最新情報の 交換をした。

5)EMC活動の公表

今年度は次の雑誌に投稿・掲載された。

「医用電機機器EMC規格の説明」をJIRAトピック スに掲載.

6) 情報交換の積極化

$\mathrm{EMC}$ 規制の不透明なアジア，才セアニア各国の 動向について重点的に情報交換を行い，情報の正確 化を図った。

（山本英明）

\section{5-17 骨密度測定装置班}

本年度本班の活動は，昨年度に引き続き「X線骨密 度測定装置用性能評価ファントム」の新規JIS化作業お よびX線骨密度測定装置第三者認証基準案の作成作業 を行った。

1)「X線骨密度測定装置用性能評価ファントム」の新規 JIS化作業

この規格であるJIS Z 4930 X線骨密度測定装置用 性能評価ファントムは, 工業標準化法第12条第 1 項 の規定に基づき，JIRA／JSAから，工業標準原案を 具して日本工業規格を制定すべきとの申し出を受け JIS原案を作成する日本工業規格である。この規格 の目的は，X線骨密度測定装置の製造または輸入を 目的とした形式試験, 性能試験および日常精度管理 を目的として，その性能を評価するためのファント
ムについて規定するものであり, 正確度などの測定 值の絶対值評価は意威しない。

当規格の審議は本年度で終了し，JIS原案として提 出する予定である。

2) X線骨密度測定装置第三者認証基準案の作成作業

当初第三者認証基準に適合する装置として基準案 の作成を行ってきたが，厚生労働省との数度にわた る検討の結果, 装置間の絶対值 $\left(\mathrm{g} / \mathrm{cm}^{2}\right)$ に相違があ り，整合性，互換性に欠けるという点が問題視さ れ，第三者認証基準の適応は難しく治験なしの承認 審査対象機器とするという方向性が強まった。

(今井宜雄)

\section{6. その他の事業}

\section{6-1 標準化フォーラムの開催}

第60回総会学術大会において第 5 回標準化フォーラ ム一放射線機器の不変性試験の普及活動および実施報 告一を開催した。

1) 口内法撮影用X線装置

司会 日本大学歯学部付属歯科病院 丸橋一夫 （1）口内法撮影用X線装置の特性と不変性試験 九州大学病院 松尾利明

(2) 整流方式の異なる口内法撮影用X線装置の不変性 試験

広島大学病院 相田雅道

(3)ディジタル画像処理を用いた口内法撮影用X線装 置の不変性試験

鶴見大学歯学部附属病院 三島 章 2) X線防護類（防護遮へい体，防護壁，防護用具）

司会 駿河台日本大学病院 伊藤敏夫

(1) 防護エプロンの不変性試験を実施して

埼玉県立小児医療センター 小島英之

（2）当院におけるX線防護具類不変性試験実施報告

日本大学医学部附属板橋病院 中村哲哉

\section{6-2 JIRA活動報告会}

第 4 回JIRA活動報告会 (10月15日10:00 16:20 医科 器械会館)において, 平成15年度審議のJIS化原案不変 性試験の発表を行った。

「医用画像部門における品質維持の評価及び日常試 験方法一第 2-11部: 不変性試験一直接撮影用X線装置 JIS Z 4752-2-11:200X」

原案作成委員会主査 安部真治 